\title{
Predictors of Left Ventricular Mass Regression Following Aortic Valve Replacement
}

\author{
Farouk M Oueida ${ }^{1 *}$, Ibrahim M Yassin ${ }^{1,2}$, Mostafa A Eissa ${ }^{1}$ \\ From World Society of Cardiothoracic Surgeons 25th Anniversary Congress, Edinburgh \\ Edinburgh, UK. 19-22 September 2015
}

\section{Background/Introduction}

Aortic stenosis (AS) is one of the most common valvular heart disease nowadays Independent factors affecting the postoperative outcome had been studied long time ago.

\section{Aims/Objectives}

Identification of the predictors of left ventricular mass regression after aortic valve replacement is our aim of this study.

\section{Method}

Randomized selection of 100 patients, underwent aortic valve replacement with a single type of bio-prosthesis (Medtronic Mosaic) for pure aortic stenosis. The study population showed that, $25 / 100(25 \%)$ patients had prosthesis-patient mismatch of a moderate degree (indexed effective orifice area (IEOA) from $0.65 \mathrm{~cm} 2 / \mathrm{m} 2$ $0.85 \mathrm{~cm} 2 / \mathrm{m} 2$ ). The effect of prosthesis-patient mismatch on the postoperative echocardiographic findings mainly the regression of left ventricular mass after aortic valve replacement and follow up comparison of the unmatched group with the matched group in addition to the other possible related factors through the multivariate analysis was studied.

\section{Results}

In multivariate analysis, hypertensive patients, preoperative New York Heart Association (NYHA) class $>$ II and a higher preoperative left ventricular mass $\leq 250 \mathrm{~g} / \mathrm{m} 2$ are independent predictors of incomplete left ventricular mass regression. Age and Gender was found to be insignificant predictors. There was a good correlation $(\mathrm{r}=$ $0.755, \mathrm{p}<0.001)$ between the postoperative left ventricular mass regression (LVMR) and the projected

${ }^{1}$ Cardiac Surgery Department, Saud al-Babtin Cardiac Center (SBCC)

Al-Dammam, 31463, KSA

Full list of author information is available at the end of the article indexed effective orifice area. There was a significant reduction of left ventricle (LV) mass in both groups and a significant reduction of LV mass index among Non PPM group while it was of a no significant reduction in PPM.

\section{Discussion/Conclusion}

This study shows that in patients with pure aortic stenosis prosthesis-patient mismatch is associated with lesser regression of left ventricular hypertrophy after aortic valve replacement. Hypertension, preoperative (NYHA) class $>$ II and a left ventricular mass $\leq 250 \mathrm{~g} / \mathrm{m} 2$ are other independent predictors.

\section{Authors' details}

${ }^{1}$ Cardiac Surgery Department, Saud al-Babtin Cardiac Center (SBCC), Al-Dammam, 31463, KSA. ${ }^{2}$ Cardiac Surgery Department, Tanta University Hospitals, Tanta, 31111, Egypt.

Published: 16 December 2015

doi:10.1186/1749-8090-10-S1-A86

Cite this article as: Oueida et al:: Predictors of Left Ventricular Mass

Regression Following Aortic Valve Replacement. Journal of Cardiothoracic Surgery 2015 10(Suppl 1):A86.

Submit your next manuscript to BioMed Central and take full advantage of:

- Convenient online submission

- Thorough peer review

- No space constraints or color figure charges

- Immediate publication on acceptance

- Inclusion in PubMed, CAS, Scopus and Google Scholar

- Research which is freely available for redistribution 